\title{
ASPECTOS DE DIREITO MATERIAL E DE DIREITO PROCESSUAL NA IN- TERPRETAÇÃO E NA APLICAÇÃO DO ARTIGO 406 DO CÓDIGO CIVIL ${ }^{1}$
}

\section{ASPECTS OF SUBSTANTIVE LAW AND PROCEDURAL LAW IN THE INTERPRE- TATION AND APPLICATION OF ARTICLE 406 OF THE CIVIL CODE}

Elias Marques de Medeiros Neto

Pós-Doutorados em Direito Processual Civil pelas Universidades de Lisboa e Coimbra/IGC. Doutor e Mestre em Direito Processual Civil pela PUCSP. Professor Doutor de Direito Processual Civil nos programas de Doutorado e Mestrado da Unimar e na graduação da Facamp. Advogado. São Paulo/SP. E-mail: emarques@tozzinifreire.com.br

Elzeane da Rocha Mestranda em Direito Processual Civil na Fadisp. Advogada. São Paulo/SP.

André Perasoli Trade Acadêmico de Direito. São Paulo/SP.

RESUMO: O presente artigo trata sobre a interpretação e a aplicação do artigo 406 do Código Civil (“CC”). Conforme se verá, a taxa do Sistema Especial de Liquidação e de Custódia ("Taxa Selic") vem sendo adotada como referência, pelo Superior Tribunal de Justiça, para o cálculo de juros de mora e de correção monetária nos termos do referido artigo do CC. Nesse sentido, buscar-se-á compreender a perspectiva histórica que gravita em torno desse debate, as razões pelas quais tal entendimento tem sido firmado - que, adiantamos, é acertado diante de nosso ordenamento - e a sua aplicação no âmbito do direito civil vigente.

\footnotetext{
${ }^{1}$ Artigo recebido em 14/05/2021 e aprovado em 07/10/2021.
} 
PALAVRAS CHAVES: Juros legais; taxa Selic; processo civil.

\begin{abstract}
This article deals with the interpretation and application of article 406 of the Civil Code ("CC"). As will be seen, the rate of the Special System for Settlement and Custody ("Selic Rate") has been adopted as a reference by the Superior Court of Justice for the calculation of default interest and monetary correction under the terms of the aforementioned article of the CC. In this sense, we will seek to understand the historical perspective that revolves around this debate, the reasons why such an understanding has been established which, we advance, is correct in view of our legal system - and its application in the scope of law current civil law.
\end{abstract}

KEYWORDS: Legal interest; selic rate; civil procedure

\title{
1. INTRODUÇÃO: JUROS E TAXA SELIC
}

\subsection{Juros: breve histórico, conceito no direito civil e sua operacionalização até a vigên- cia do Código Civil vigente no Brasil}

Bem verdade que se trata de tópos afirmar que diversos de nossos institutos de direito privado possuem origem no sistema jurídico romano. Mesmo assim, sua importância ainda se faz presente para o entendimento de certos conceitos.

Tendo isso em vista, importa rememorar que o campo do direito das obrigações e, mais especificamente, as teorias sobre mora e seus efeitos, foram construídas a partir dos alicerces deste modelo.

Sobre as consequências da mora no direito romano, Gaetano Sciasia e Alexandre Correia, brilhantes acadêmicos, asseveravam que ${ }^{2}$ :

\begin{abstract}
"A mora culposa produz os seguintes efeitos: (a) perpetua a obrigação; i.é, enquanto a obrigação não for satisfeita, permanece. O responsável pela tardança não pode alegar perda da coisa, por caso fortuito, senão provando que a coisa teria perecido ainda se a tivesse pago; (b) o sujeito em mora responde por todos os lucros que a outra parte podia ter tido e não teve, por
\end{abstract}

\footnotetext{
${ }^{2}$ CORREIA, Alexandre; SCIASIA, Gaetano. Manual de Direito Romano e textos em correspondência com os artigos do Código Civil Brasileiro. Vol. 1. 4ª ed. São Paulo: Editora Saraiva, 1961, p. 246.
} 
causa da tardança (lucros cessantes): além disso, responde pelos prejuízos causados à outra parte (damnos emergentes)."

Dentro da noção de restituir o credor ao estado em que estava antes, havia uma brevíssima noção de juros nos fideicomissos, como se denota das Institutas de Gaio, Livro 2, título $280^{3}$.

Em estudo aprofundado sobre o direito bancário, Antônio Menezes de Cordeiro aponta que os juros, em grande parte da história jurídica ocidental, encontravam entraves para sua aplicação e sistematização, primordialmente por conta da filosofia aristotélica, já que o mútuo era visto, em comunidades humanas primitivas, como uma demonstração de relações de entreajuda e de solidariedade básicas ${ }^{4}$.

Apenas em $1757^{5}$, após o terremoto de 1755 de Lisboa, o direito lusitano viu a necessidade de introduzir os juros em sua lógica. Já, no Brasil, o Código Comercial de 1850 dedicou o Título XI à regulação dos juros mercantis.

No âmbito do direito civil, podemos indicar que Teixeira de Freitas, em sua Consolidação das Leis Civis, previa um teto de seis por cento ao ano para as taxas de juros, conforme artigo $363^{6}$.

\footnotetext{
3 "Item fideicomissorum usurae et fructus debentur, si modo moram solutionis fecerit qui fideicomissum debebit; legatorum vero usurae non debentur: idque rescripto divi Hadriani significatur. ” Tradução livre: Também se devem os juros e frutos dos fideicomissos, se o devedor fideicomissário incorrer em mora; mas os juros dos legados não são devidos, como o dispõe um rescrito do imperador Adriano.

4 "O pensamento grego, na vertente aristotélica, considerava o dinheiro estéril: logo não poderia originar juros. A lei judaica, por seu turno, só permitia a cobrança de juros nas relações com estranhos: não entre judeus. $\mathrm{O}$ Novo Testamento contém, igualmente, apelos à gratuidade dos empréstimos. Toda esta tradição tem um fundamento histórico: o mútuo, nas comunidades humanas primitivas, era uma demonstração de relações de entreajuda e de solidariedade básicas: exigir remuneração equivalia à exploração da necessidade alheia, introduzindo um fator de quebra social.

Compreende-se, assim, o pensamento cristão: partidário, em rigor, de uma pura e simples distribuição igualitária dos bens, o cristianismo primitivo nunca contemporizaria com juros. Esta posição seria reforçada com a confluência das escrituras e do pensamento aristotélico." - CORDEIRO, António Menezes. Direito Bancário. $6^{a}$ ed. Coimbra: Edições Almedina S.A., 2018, p. 677.

${ }_{6}^{5}$ Idem, p. 678.

6 "Art. 363. "Quando alguém fôr condemnado em Juízo á pagar juros, que não fossem taxados por convenção, contarsehão á seis por cento ao anno.”.
} 
O Código Civil de 1916, na mesma direção, fixou os juros moratórios ${ }^{7}$ e os juros legais $^{8}$, quando não estipulados, em seis por cento ao ano. Interessante apontar, além disso, que o diploma tornava obrigatórios os juros de mora? ${ }^{9}$.

De qualquer modo, no direito civil pátrio, os juros eram vistos como frutos do capital, como preceituava Washington de Barros Monteiro ${ }^{10}$ : "Juros são o rendimento do capital, os frutos produzidos pelo dinheiro. Assim como o aluguel constitui o preço correspondente ao uso da coisa no contrato de locação, representam os juros a renda de determinado capital."

Silvio Rodrigues acrescenta11: “Juro é o preço do uso do capital. Vale dizer, é o fruto produzido pelo dinheiro, pois é como fruto civil que a doutrina o define. Ele a um tempo remunera o credor por ficar privado de seu capital e paga-lhe o risco em que incorre de o não receber de volta."

Antunes Varela, um dos nomes mais influentes para nossa doutrina, ainda, considerava-os como forma de mensurar os prejuízos pela mora ${ }^{12}$ :

Passados esses breves apontamentos sobre a história dos juros no direito privado, possível é analisar, então, a Taxa Selic e, posteriormente, sua aplicação no CC pelo artigo 406.

\subsection{Taxa Selic}

Após o segundo choque do petróleo, em 1979, a conjuntura econômica brasileira passou por graves percalços. O país "atravessava também uma crise de divida externa, com

\footnotetext{
7 "Art. 1.062. A taxa dos juros moratórios, quando não convencionada (art. 1.262), será de seis por cento ao ano.".

8 "Art. 1.063. Serão também de seis por cento ao ano os juros devidos por força de lei, ou quando as partes os convencionarem sem taxa estipulada.".

9 “Art. 1.064. Ainda que se não alegue prejuízo, é obrigado o devedor aos juros da mora, que se contarão assim às dívidas em dinheiro, como às prestações de outra natureza, desde que lhes esteja fixado o valor pecuniário por sentença judicial, arbitramento, ou acordo entre as partes.".

${ }^{10}$ MONTEIRO, Washington de Barros. Curso de direito civil, v. 4. $14^{\mathrm{a}}$ ed. São Paulo: Saraiva, 1976, p. 337.

${ }^{11}$ RODRIGUES, Silvio. Direito civil. Vol. 2. 24a ed. São Paulo: Saraiva: 2002, p. 257.

12 “"Por outro lado, e como contrapartida, entende-se que os prejuízos indenizáveis se medem sistematicamente pelos juros (legais ou convencionais) da soma em dívida (art. 1.062). Juros que serão os estipulados, quando se trate de obrigação a juros ou quando haja cláusula penal convencionada entre as partes (os juros moratórios coincidem, nesse caso, com os juros compensatórios). E que serão, na falta de estipulação de juros ou de cláusula penal convencionada, os juros legais (de 6\% ao ano, nos termos do art. 1.062)." (VARELA, Antunes. Direito das obrigações, vol. 2. Rio de Janeiro: Forense, 1978, p. 147).
} 
o esgotamento do modelo de financiamento através de recursos externos e problemas em seu balanço de pagamentos", como aponta Larissa Naves de Deus Dornelas ${ }^{13}$.

A autora indica, aliás, que foi nesse contexto que se justificou a criação do Sistema Especial de Liquidação e de Custódia. A Taxa SELIC, por sua vez, considerada taxa básica de juros pois utilizada em operações bancárias, foi instituída em 4 de março de 1999 pelo Banco Central.

Como dispõe o Banco Central do Brasil ${ }^{14}$ :

"A Selic é a taxa básica de juros da economia. É o principal instrumento de política monetária utilizado pelo Banco Central (BC) para controlar a inflação. Ela influencia todas as taxas de juros do país, como as taxas de juros dos empréstimos, dos financiamentos e das aplicações financeiras.

A taxa Selic refere-se à taxa de juros apurada nas operações de empréstimos de um dia entre as instituições financeiras que utilizam títulos públicos federais como garantia. O BC opera no mercado de títulos públicos para que a taxa Selic efetiva esteja em linha com a meta da Selic definida na reunião do Comitê de Política Monetária do BC (Copom)".

Tendo em vista o conceito e a importância da Taxa SELIC, podemos então analisar o artigo 406 do CC para entender se seria esta a taxa de juros aplicável e adequada.

\section{ARTIGO 406 DO CÓDIGO CIVIL: ASPECTOS MATERIAIS}

“Art. 406. Quando os juros moratórios não forem convencionados, ou o forem sem taxa estipulada, ou quando provierem de determinação da lei, serão fixados segundo a taxa que estiver em vigor para a mora do pagamento de impostos devidos à Fazenda Nacional".

\subsection{Evolução doutrinária}

Com a entrada em vigor do Código Civil vigente, levantaram-se diversas questões sobre a taxa de juros adotada pelo legislador no artigo 406 do CC. Sintetiza Caio Mário da Silva Pereira tal debate ${ }^{15}$ :

\footnotetext{
${ }^{13}$ DORNELAS, Larissa Naves de Deus. SELIC: o mercado brasileiro de dívida pública. Campinas: Alínea, 2021, p. 48.

${ }^{14}$ Disponível em: https://www.bcb.gov.br/controleinflacao/taxaselic.

${ }^{15}$ PEREIRA, Caio Mário da Silva. Instituições de direito civil. Vol. II. $22^{\mathrm{a}}$ ed. Rio de Janeiro: Editora Forense, 2009, pp. 337-338.
} 
"A grande divergência trazida pelo referido art. 406, do Código Civil de 2002, diz respeito exatamente à correta interpretação da expressão "segundo a taxa que estiver em vigor para a mora do pagamento de impostos devidos à Fazenda Nacional". Duas correntes doutrinárias se formaram a respeito de tal questão: a) aquela que defende a adoção da taxa SELIC (taxa referencial adotada no Sistema Especial de Liquidação e Custódia para os títulos públicos federais) da Lei $\mathrm{n}^{\circ} 8.981 / 95$; b) aquela segundo a qual deve ser considerado o percentual de $1 \%$ ao mês, ou seja, $12 \%$ a.a. (doze por cento ao ano), nos termos do art. $161, \S 1^{\circ}$, do Código Tributário Nacional (CTN)."

O respeitável autor, na época, se filiava à segunda corrente que, por muito tempo, prevaleceu em nossos Tribunais de acordo com o Enunciado n ${ }^{\circ} 20$ da I Jornada de Direito Civil promovida pelo Conselho da Justiça Federal: "20 - Art. 406: a taxa de juros moratórios a que se refere o art. 406 é a do art. 161, \$1 , do Código Tributário Nacional, ou seja, um por cento ao mês."

Ainda desse lado da doutrina, podemos destacar a opinião de Judith-Martins Costa, que criticava a aplicação da Selic por ser uma taxa flutuante e que não refletia a taxa de juros reais ${ }^{16}$, baseando-se no artigo $192, \S 3^{\circ}$ da Constituição Federal ${ }^{17}$, atribuindo-lhe uma eficácia inibitória.

Ainda, Arnoldo Rizzardo, com base (i) em jurisprudência do Superior Tribunal de Justiça que considerava inconstitucional e ilegal a aplicação da taxa Selic para fins tributários e (ii) nas violações de princípios da anterioridade, legalidade, e indelegabilidade de competência, concluía pela sua inaplicabilidade. Ressaltava, ainda, que a aplicação da Taxa Selic poderia provocar acréscimos contrários à razoabilidade ${ }^{18}$.

Apesar das hercúleas tentativas de afastar a aplicação da Taxa Selic como taxa remuneratória e de correção monetária em causas cíveis, prevaleceu, nos anos posteriores, a posição contrária.

\footnotetext{
16 "Ora, constituindo uma "taxa flutuante" sujeita a todas essas injunções de uma específica parcela do mercado, se há de convir que em nenhuma hipótese a taxa SELIC refletirá a "taxa de juros reais", de modo que não serve para os fins do art. 406. O próprio sistema oferece, contudo, solução para a aparente lacuna." - MARTINSCOSTA, Judith. Comentários ao novo Código civil, volume V, tomo II: do inadimplemento das obrigações. Rio de Janeiro: Forense, 2003, p. 402.

${ }^{17}$ Revogado pela Emenda Constitucional n ${ }^{\circ} 40$, de 2003.

${ }^{18} \mathrm{Cf}$. "Os juros podem trazer um encargo insuportável, se prevalecer o critério da sua correspondência à taxa Selic. Com efeito, se fixada esta última cumulativamente em, v.g., $25 \%$ ao ano, e previstos os juros moratórios e compensatórios, sujeitará o devedor a um acréscimo, só neste fator, em $50 \%$ ao ano. Adotando-se a diretriz do art. 161, § 1. ${ }^{\circ}$, do CTN (LGL11966।26), o máximo que atingirão as duas taxas é $24 \%$ ao ano de aumento, o que importa em certa razoabilidade, viabilizando o cumprimento." - RIZZARDO, Arnaldo. Juros no Código Civil de 2002. In: Revista de Direito Bancário e do Mercado de Capitais. Vol. 22, out.-dez./2003.
} 
Rodrigo Garcia da Fonseca ${ }^{19}$, em aprofundado estudo sobre o tema, manifestou-se contrário a todos os argumentos apresentados pela Doutrina na época. Em primeiro lugar, a adoção de taxa flutuante teria sido escolha do legislador, assim como a remissão do referido artigo ao ordenamento tributário.

Sobre suposto bis in idem, adverte que o próprio STJ - como se verá adiante - já entendia a aplicação da Taxa Selic tanto como juros moratórios quanto como correção monetária. Sobre suposta inconstitucionalidade, traz julgados do Supremo Tribunal Federal para demonstrar claramente a constitucionalidade da opção do legislador.

Assim, conclui o autor, de forma brilhante ${ }^{20}$ : “Na realidade, afastar a taxa Selic para aplicar a taxa fixa de 1\% ao mês, seja nas questões tributárias, seja nas civis, configura uma exegese nitidamente contra legem. Não cabe ao intérprete se substituir ao legislador, para dizer que o direito é o que se acha que deveria ser, e não o que realmente é."

Em artigo mais recente, Marcos Cavalcante de Oliveira apresenta uma perspectiva extremamente benquista à doutrina enfrentando os argumentos contrários e entendendo a aplicação da Taxa Selic como essencial para o reforço das obrigações. ${ }^{21}$

Em suma, diante da inegável constitucionalidade do artigo 406, da obediência da escolha do legislador e do estímulo ao cumprimento tempestivo das obrigações, torna-se inafastável a aplicação da Taxa Selic às causas cíveis por força do artigo 406 do Código Civil.

Assim, analisaremos os posicionamentos do Superior Tribunal de Justiça desde 2006 para verificar se este é o entendimento que prevalece em nossos tribunais.

\subsection{Posicionamento do STJ entre 2006 e 2008}

\footnotetext{
${ }^{19}$ FONSECA, Rodrigo Garcia da. Os Juros e o Novo Código Civil. In: Revista de Direito Bancário e do Mercado de Capitais. Vol. 26. Out.-dez., 2004.

${ }^{20}$ Idem.

21 “A argumentação apresentada nos itens anteriores mostrou que a aplicação da taxa Selic às hipóteses de incidência do art. 406 do CC/2002 (LGL12002\400) é não apenas a conclusão natural a que se chega da leitura da letra do texto legal, como também consistente com uma interpretação sistemática do direito positivo brasileiro, e, ainda mais importante, a única solução legislativa que devolve aos juros moratórios o seu poder de efetivamente servir como reforço à sua finalidade econômica e social, que é estimular as partes ao tempestivo cumprimento de suas obrigações." (OLIVEIRA, Marcos Cavalcante de. A Taxa Selic e o art. 406 do CC/02. In: Revista dos Tribunais. Vol. 857. Mar., 2007).
} 
Inicialmente, havia certa divisão de entendimento do Superior Tribunal de Justiça. A $2^{\mathrm{a}}$ Turma prontamente adotou a aplicação da Taxa Selic ao artigo 406 do Código Civil, entendendo que esta incluía tanto os juros legais quanto a correção monetária, conforme os seguintes julgados:

“2. Com o advento do novo Código Civil, quando não convencionados os juros moratórios, ou o forem sem taxa estipulada, ou quando provierem de determinação da lei, serão fixados segundo a taxa que estiver em vigor para a mora do pagamento de impostos devidos à Fazenda Nacional; por enquanto, a taxa SELIC (a partir da citação), com a advertência de que não pode ser ela cumulada com qualquer outro índice de correção monetária, porque já embutida no indexador."222 23

A $1^{\text {a }}$ Seção deliberou sobre o tema no mesmo sentido:

"PROCESSO CIVIL. RECURSO ESPECIAL. JUROS DE MORA. TAXA SELIC. APLICABILIDADE. ART. 406 DO NOVO CÓDIGO CIVIL.

1. Os juros moratórios, nas ações em que se discute a inclusão de expurgos inflacionários nas contas vinculadas ao FGTS, são devidos a partir da citação - que nos termos do arts. 219 do Código de Processo Civil e 406 do Código Civil vigentes, constitui o devedor em mora -, à base de $0,5 \%$ (meio ponto percentual) ao mês até a entrada em vigor do Novo Código Civil (Lei n. $\left.{ }^{\circ} 10.406 / 2001\right)$ e, a partir de então, segundo a taxa que estiver em vigor para a mora do pagamento de impostos devidos à Fazenda Nacional (art. 406). Taxa esta que, como de sabença, é a SELIC, nos expressos termos da Lei n. ${ }^{\circ}$ 9.250/95 (Precedentes: REsp n. ${ }^{\circ}$ 666.676/PR, Segunda Turma, Rel. Min. Eliana Calmon, DJU de 06/06/2005; e REsp n. ${ }^{\circ}$ 803.628/RN, Primeira Turma, deste Relator, DJU de 18/05/2006)." ${ }^{24}$

Do outro lado, a $3^{\mathrm{a}}$ Turma se pronunciou pela aplicação do artigo 161, § $1^{\circ}$, do CTN:

"AGRAVO REGIMENTAL. JUROS DE MORA. NOVO CÓDIGO CIVIL. RELAÇÃO JURÍDICA ENTRE PARTICULARES. INAPLICABILIDADE DA SELIC. PRETENSÃO DE PÓS-QUESTIONAR. INVIABILIDADE.

1. Até a data da entrada em vigor do novo Código Civil, o juros moratórios são regulados pelo artigo 1.062 do Código Beviláqua. Depois daquela data, aplica-se a taxa prevista no artigo 406 do atual Código Civil, na razão de 1 $\%$ ao mês.

2. A taxa SELIC tem aplicação específica a casos previstos em Lei, tais como restituição ou compensação de tributos federais. Não é a ela que se refere o Art. 406 do novo Código Civil, mas ao percentual previsto no Art. $161, \S 1^{\circ}$, do CTN.

\footnotetext{
${ }^{22}$ STJ, REsp 781594/PE, $2^{\mathrm{a}}$ Turma, Min ${ }^{\mathrm{a}}$. Rel ${ }^{\mathrm{a}}$. Eliana Calmon, j. 16.05.2006.

23 "2. Os juros de mora devem incidir na correção do saldo das contas vinculadas do FGTS no percentual de $0,5 \%$ ao mês até a data de entrada em vigor do Novo Código Civil. A partir de então, deverá incidir a Selic (Lei n. 9.250/95), taxa que está em vigor para a mora do pagamento de impostos devidos à Fazenda Nacional (art. 406 do Código Civil de 2002).” - STJ, REsp 916567/PE, $2^{a}$ Turma, Min. Rel. João Otávio de Noronha, 27.03.2007.

${ }^{24}$ STJ, REsp 875919/PE, 1ª Seção, Min. Rel. Luiz Fux, j. 13.06.2007.
} 
Revista Eletrônica de Direito Processual - REDP.

Rio de Janeiro. Ano 16. Volume 23. Número 1. Janeiro a Abril de 2022

Periódico Quadrimestral da Pós-Graduação Stricto Sensu em Direito Processual da UERJ

Patrono: José Carlos Barbosa Moreira (in mem.). ISSN 1982-7636. pp. 416-433

www.redp.uerj.br

3. Em recurso especial não se acolhe a pretensão de pós-questionar dispositivos constitucionais." 25

Sucede que, em embargos de divergência, a matéria foi decidida pela Corte Especial, que votou pela aplicação da Taxa Selic:

"CIVIL. JUROS MORATÓRIOS. TAXA LEGAL. CÓDIGO CIVIL, ART. 406. APLICAÇÃO DA TAXA SELIC.

1. Segundo dispõe o art. 406 do Código Civil, "Quando os juros moratórios não forem convencionados, ou o forem sem taxa estipulada, ou quando provierem de determinação da lei, serão fixados segundo a taxa que estiver em vigor para a mora do pagamento de impostos devidos à Fazenda Nacional".

2. Assim, atualmente, a taxa dos juros moratórios a que se refere o referido dispositivo é a taxa referencial do Sistema Especial de Liquidação e Custódia - SELIC, por ser ela a que incide como juros moratórios dos tributos federais (arts. 13 da Lei 9.065/95, 84 da Lei 8.981/95, 39, § $4^{\circ}$, da Lei 9.250/95, 61, § $3^{\circ}$, da Lei 9.430/96 e 30 da Lei 10.522/02).

3. Embargos de divergência a que se dá provimento."26

A partir desse julgado, o STJ adotou firme posicionamento pela aplicação da Selic como taxa de juros legais ${ }^{27}$.

\subsection{Posicionamento do STJ entre 2009 e 2014}

\footnotetext{
${ }^{25}$ STJ, AgRg no REsp 727842/SP, $3^{\text {a }}$ Turma, Min. Rel Humberto Gomes de Barros, j. 03.12.2007.

${ }^{26}$ STJ, EREsp 727842 / SP, Corte Especial, Min. Rel. Teori Albino Zavascki, j. 08.09.2008.

${ }^{27}$ Nessa toada:

“AGRAVO DE INSTRUMENTO. EXECUÇÃO. PRECATÓRIO COMPLEMENTAR. JUROS MORATÓRIOS. MOMENTO DA INCIDÊNCIA. CRITÉRIOS. VIGÊNCIA NOVO CÓDIGO CIVIL.

I - Trata-se de discussão acerca da incidência de juros moratórios em precatório complementar, em autos de execução de título judicial, onde o Tribunal a quo determinou que tais juros incidam à razão de $0,5 \%$ ao mês durante a vigência do Código Civil/1916 e, a partir do Novo Código, em 1\% ao mês.

II - Sob o argumento de que a indenização que gerou a referida execução se deu na vigência do Código Civil/1916, pretende o recorrente que durante todo o período os juros moratórios sejam fixados em $0,5 \%$ ao mês. III - Esta eg. Corte de Justiça já tem firme posicionamento no sentido de que os juros de mora são devidos à taxa de $0,5 \%$ ao mês, até a vigência do Código Civil de 2002, a partir de quando deve ser considerada a taxa que estiver em vigor para a mora no pagamento de impostos devidos à Fazenda Nacional (artigo 406), ou seja, a SELIC. Precedentes: AgRg no REsp n 972.590/PR, Rel. Min. JOSÉ DELGADO, DJe de 23.06.2008; REsp $n^{\circ}$ 858.011/SP, Rel. Min. DENISE ARRUDA, DJe de 26/05/2008; REsp nº 926.140/DF, Rel. Min. LUIZ FUX, DJe de 12.05.2008.

IV - Assim, a pretensão estadual é descabida e, por outro lado, considerando-se a peculiaridade da espécie, deve ser mantido o entendimento firmado pelo juízo a quo sobre o percentual dos juros moratórios, nada podendo se deliberar nestes autos sobre a incidência da SELIC, em observância ao princípio da non reformatio in pejus.

V - Recurso improvido.” - STJ, REsp 926285 / PR, 1ª Turma, Min. Rel. Francisco Falcão, j. 14.10.2008.
} 
Revista Eletrônica de Direito Processual - REDP.

Rio de Janeiro. Ano 16. Volume 23. Número 1. Janeiro a Abril de 2022

Periódico Quadrimestral da Pós-Graduação Stricto Sensu em Direito Processual da UERJ

Patrono: José Carlos Barbosa Moreira (in mem.). ISSN 1982-7636. pp. 416-433

www.redp.uerj.br

Apenas para elucidar quão pacífico se tornou o tema no STJ, apontamos os seguintes julgados (incluindo aqui julgados da $3^{\text {a }}$ Turma, que havia se posicionado contrariamente nos primeiros casos):

“3. A Corte Especial deste Tribunal pacificou o entendimento de que atualmente a taxa de juros moratórios a que se refere o art. 406 do Código Civil é a Selic." 282930

"1. "Os juros (de mora) legais devem ser fixados à taxa de $0,5 \%$ ao mês (artigo 1.062 do CC/1916) no período anterior ao início da vigência do novo Código Civil (10.1.2003) e, em relação ao período posterior, nos termos do disposto no artigo 406 do Código Civil de 2002, o qual corresponde à Taxa SELIC". (AgRg no Ag 1370108/SP, Rel. Ministro SIDNEI BENETI, TERCEIRA TURMA, julgado em 12/04/2011, DJe 27/04/2011)"31 3233

“6. Sobre os valores apurados em liquidação de sentença devem recair, até o efetivo pagamento, juros moratórios de $6 \%$ ao ano a partir da citação, nos termos dos arts. 1.062 e 1.063 do CC/1916, até 11.1.2003, quando passou a se aplicar a Taxa Selic (art. 406 do CC atual)."3435

${ }^{28}$ STJ, REsp 945601 / SC, $2^{\mathrm{a}}$ Turma, Min ${ }^{\mathrm{a}}$. Rel ${ }^{\mathrm{a}}$. Eliana Calmon, j. 16.06.2009.

29 “4. Os juros de mora, devidos in casu a partir do evento danoso (Súmula 54/STJ), devem ser calculados à base de 0,5\% ao mês, nos termos do artigo 1.062 do Código Civil de 1916 até a entrada em vigor do Novo Código Civil (Lei n ${ }^{\circ}$ 10.406/2001), devendo observar, a partir de então, a taxa que estiver em vigor para a mora do pagamento de impostos devidos à Fazenda Nacional (artigo 406). Taxa esta que, como de sabença, é a SELIC, nos expressos termos da Lei no 9.250/95 (Precedente da Corte Especial: EREsp 727.842/SP, Rel. Min. TEORI ALBINO ZAVASCKI, DJe de 20/11/2008)

5. A incidência da taxa SELIC a título de juros moratórios, a partir da entrada em vigor do atual Código Civil, em janeiro de 2003, exclui a incidência cumulativa de correção monetária, sob pena de bis in idem (Precedente: EDcl no REsp 1077077/SP, Rel. Min. SIDNEI BENETI, TERCEIRA TURMA, DJe de 05/06/2009)" - STJ, EDcl no REsp 961512 / SP, $3^{\text {a }}$ Turma, Min. Rel. Vasco Della Giustina, j. 14.12.2010.

30 “5. Nas obrigações ainda não adimplidas, anteriores à vigência do CC/02, a jurisprudência tem se orientado no sentido de reputar aplicável, quanto aos juros, o art. 1.062 do CC/16 até a data de 10/1/2003, e o art. 406 do $\mathrm{CC} / 02$ após essa data. Precedentes.

6. O índice que deve ser aplicado de conformidade com o art. 406 do CC/02 é, consoante precedente da Corte Especial, a Taxa SELIC, não obstante a existência de julgados recentes aplicando, à espécie, o art. 161, $\S 1^{\circ}$, do CTN.

7. A taxa SELIC abrange juros e correção monetária, não pode ser cumulada a nenhum outro índice que exprima tais consectários." - STJ, EDcl no REsp 953460 / MG, 3 ${ }^{\mathrm{a}}$ Turma, Min. Rel ${ }^{\mathrm{a}}$. Nancy Andrighi, j. 09.08.2011.

${ }^{31}$ STJ, AgRg no REsp 886970 / DF, 4 $4^{\mathrm{a}}$ Turma, Min. Rel. Luis Felipe Salomão, j. 16.08.2011.

32 “3. A taxa de juros moratórios a que se refere o art. 406 do Código Civil de 2002, segundo precedente da Corte Especial (EREsp 727842/SP, Rel. Ministro TEORI ALBINO ZAVASCKI, CORTE ESPECIAL, julgado em 08/09/2008), é a SELIC, não sendo possível cumulá-la com correção monetária, porquanto já embutida em sua formação.” - STJ, EDcl no REsp 1025298 / RS, 2a Seção, Min. Rel. Luis Felipe Salomão, j. 28.11.2012.

33 "7. Os juros de mora incidem desde o evento danoso, à taxa de $0,5 \%$ ao mês até a entrada em vigor do CC/2002, e pela Taxa Selic após essa data (EREsp n. 727.842/SP, Rel. Ministro TEORI ALBINO ZAVASCKI, CORTE ESPECIAL, DJe de 20/11/2008).” - STJ, REsp 645729 / RJ, 4ª Turma, Min. Rel. Antonio Carlos Ferreira, j. 11.12.2012.

${ }^{34}$ STJ, AgRg no AREsp 311954 / PR, 2 ${ }^{\mathrm{a}}$ Turma, Min. Rel. Herman Benjamin, j. 28.05.2013.

35 "2. Os valores a serem restituídos pelo banco serão acrescidos de juros remuneratórios de $1 \%$ ao mês, corrigidos monetariamente pelo INPC, mais juros de mora de $0,5 \%$ ao mês desde a citação e, após a vigência do novo Código Civil, da taxa Selic, índice comum de juros moratórios e correção monetária, na forma do art. 


\subsection{Posicionamento do STJ entre 2014 e 2019}

Ainda, conforme o posicionamento apontado:

"2. Os juros de mora incidem desde o evento danoso, à taxa de $0,5 \%$ ao mês até a entrada em vigor do CC/2002, e pela Taxa Selic após essa data (EREsp 727.842/SP, Rel. Ministro TEORI ALBINO ZAVASCKI, Corte Especial, DJe de 20/11/2008)." ${ }^{3637}$

"1. O Superior Tribunal de Justiça, em julgamento submetido ao rito dos processos representativos da controvérsia (art. 543-C do CPC/1973 e art. 1.036 do CPC/2015) firmou o entendimento de que a taxa dos juros moratórios a que se refere o art. 406 do CC/2002 é a taxa referencial do Sistema Especial de Liquidação e Custódia - SELIC 2. Agravo interno não provido." 3839

"3. Os juros moratórios são devidos a partir do evento danoso no percentual de 0,5\% a.m até a entrada em vigor do Código Civil atual (11.1.2003), quando deverão ser calculados na forma do seu art. 406, isto é, de acordo com a SELIC." 40

\subsection{Posicionamento atual do STJ}

Como se pode imaginar, o STJ, para fins do artigo 406 do CC, manteve sua posição sobre a aplicação da taxa SELIC nos últimos dois anos, como se depreende dos seguintes julgados, apenas a título exemplificativo:

\section{"AGRAVO INTERNO. RECURSO ESPECIAL. RESPONSABILIDADE CIVIL. JUROS DE MORA. TAXA SELIC. INCIDÊNCIA. PRECEDEN- TES. NÃO PROVIMENTO. \\ 1. "A Corte Especial no julgamento de recurso especial repetitivo entendeu que por força do art. 406 do CC/02, a atualização dos débitos judiciais deve ser efetuada pela taxa referencial do Sistema Especial de Liquidação e Cus- tódia - SELIC, a qual deve ser utilizada sem a cumulação com correção monetária por já contemplar essa rubrica em sua formação" (AgInt no}

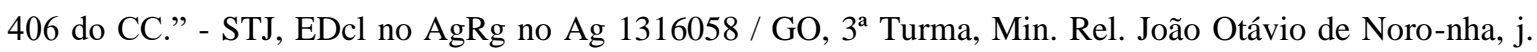
10.09.2013.

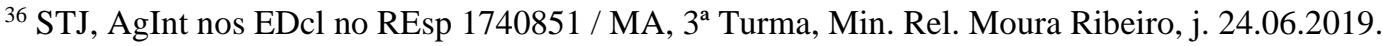

37 “1. Esta Corte firmou entendimento no sentido de que a fixação da taxa dos juros moratórios, a partir da entrada em vigor do artigo 406 do Código Civil de 2002, deve ser com base na taxa Selic, podendo essa tese ser aplicada inclusive nos casos em que se discute a execução de honorários. Precedentes." - STJ, AgInt no AREsp 1180613 / MS, 4 $4^{\text {a }}$ Turma, Min. Rel. Marco Buzzi, j. 21.10.2019.

${ }^{38}$ STJ, AgInt no REsp 1628809 / SP, $3^{\text {a }}$ Turma, Min. Rel. Ricardo Villas Bôas Cueva, j. 18.05.2017.

39 "3. O Tribunal de origem, ao discorrer sobre os juros moratórios, entendeu que seu termo inicial será a partir da citação e na base de $6 \%$ ao ano até a entrada em vigor do Código Civil, aplicada a taxa Selic, a partir de então, consoante interpretação feita do art. 406 do Código Civil, que se coaduna com jurisprudência desta Corte." - , STJ, AgInt no AREsp 870448 / SP, 2a Turma, Min. Rel. Humberto Martins, j. 18.08.2016.

${ }^{40}$ STJ, AgRg no REsp 831173 / RJ, 4ª Turma, Min. Rel. Raul Araujo, j. 16.12.2014. 
A orientação hodierna apenas segue, como mencionado previamente, os julgados da

Corte Especial. Além do EREsp 727842 / SP, importante apontar que, em sede de recurso especial repetitivo, a Corte Especial firmou a seguinte tese na sessão de 02 de junho de 2010 :

"Tema 176: Tendo sido a sentença exequenda prolatada anteriormente à entrada em vigor do Novo Código Civil, fixado juros de $6 \%$ ao ano, correto o entendimento do Tribunal de origem ao determinar a incidência de juros de $6 \%$ ao ano até 11 de janeiro de 2003 e, a partir de então, da taxa a que alude o art. 406 do Novo CC, conclusão que não caracteriza qualquer violação à coisa julgada."

Constata-se, a partir da orientação do Superior Tribunal de Justiça, que a taxa oficial de juros legais - prevista pelo artigo 406 do CC - é a Taxa Selic.

\subsection{Conclusão do ponto de vista de direito material}

O posicionamento firmado pela aplicação da taxa SELIC para atualização monetária e juros de mora não atinge apenas o direito civil, como têm decidido o STJ e o STF.

Cita-se, como exemplo, a Ação Direta de Inconstitucionalidade n. 5.867/DF, que estendeu aos depósitos recursais e aos débitos trabalhistas na justiça do trabalho a aplicação da SELIC após a citação ${ }^{43}$.

\footnotetext{
${ }^{41}$ STJ, AgInt no REsp 1723791 / MS, 4 ${ }^{\text {a }}$ Turma, Min ${ }^{a}$. Rel ${ }^{\text {a }}$ Maria Isabel Gallotti, j. 08.02.2021.

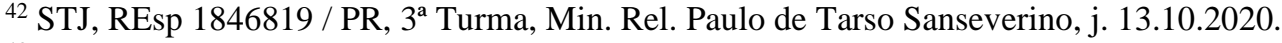

43 "Ações diretas de inconstitucionalidade e ações declaratórias de constitucionalidade. 2. Art. 879, $\$ 7^{\circ}$, e art. 899, $\S 4^{\circ}$, da CLT, na redação dada pela Lei 13. 467, de 2017. Art. 39, caput e $§ 1^{\circ}$, da Lei 8.177 de 1991. 3. Constitucionalidade dos índices de correção dos depósitos recursais e dos débitos trabalhistas na justiça do trabalho. 4. Política de correção ADI 5867 / DF monetária e tabelamento de juros. Institucionalização da Taxa Referencial - TR como política de desindexação da economia. Combate histórico a processos inflacionários. Risco de constitucionalização de normas financeiras e do sistema monetário nacional. 5. TR como índice de correção monetária. Inconstitucionalidade. Precedentes do STF. 6. Apelo ao legislador. Aplicação, até que sobrevenha solução legislativa, dos mesmos índices de correção monetária e de juros vigentes para as hipóteses de condenações cíveis em geral: IPCA-E na fase pré-judicial e SELIC a partir da citação. 7. Ações diretas de inconstitucio-nalidade e ações declaratórias de constitucionalidade julgadas parcialmente procedentes, para con-ferir interpretação conforme à Constituição ao art. $879, \S 7^{\circ}$, e ao art. $899, \S 4^{\circ}$, da CLT, na redação dada pela Lei 13.467, de 2017. 8. Modulação de efeitos." (STF, ADIn n. 5.867/DF, Plenário, Min. Rel. Gilmar Mendes, j. 18.12.2020)
} 
Acerca da aplicação para fins tributários, merece também destaque o Tema Repetitivo 199, que determinou a aplicação da Taxa Selic como índice de correção monetária e de juros de mora na atualização de débitos tributários pagos em atraso.

Por conseguinte, do ponto de vista do direito civil, resta patente a plena aplicabilidade da Taxa Selic como juros legais previstos no artigo 406 do CC vigente. Ressalte-se que, conforme supracitado, a taxa Selic inclui tanto os juros moratórios quanto a correção monetária.

\subsection{Aspectos processuais sobre o artigo 406 do CC}

Há algumas questões processuais que orbitam ao redor de institutos relevantes do direito processual civil.

Primordialmente, deve-se compreender que, segundo entendimento do STJ, os juros legais são matéria de ordem pública:

"2. Esta Corte já definiu que não há falar em reformatio in pejus quando o Tribunal altera tão somente os consectários legais, por integrarem o pedido de forma implícita. É matéria de ordem pública, cognoscível de ofício." 44 "1. A correção monetária, assim como os juros de mora, incide sobre o objeto da condenação judicial e não se prende a pedido feito em primeira instância ou a recurso voluntário dirigido à Corte de origem. É matéria de ordem pública, cognoscível de ofício em sede de reexame necessário, máxime quando a sentença afirma a sua incidência, mas não disciplina expressamente o modo como essa obrigação acessória se dará no caso." ${ }^{\$ 5} 46$ "2. Por se tratar de matéria de ordem pública, é possível a esta Corte proceder à adequação da incidência dos juros de mora, a fim de que, no cálculo da dívida, seja utilizado o percentual de $0,5 \%$ até a vigência do novo $\mathrm{CC}$, aplicando-se, a partir daí, a taxa SELIC, sem que tal fato configure reformatio in peius, tampouco ofensa à coisa julgada." 47

Como adverte Heitor Vitor Mendonça Sica, as questões de ordem pública podem ser reconhecidas, mesmo de ofício, até a formação da coisa julgada ${ }^{48}$.

\footnotetext{
${ }^{44}$ STJ, AgRg no AREsp 324626 / SP, $2^{\text {a }}$ Turma, Min. Rel. Humberto Martins, j. 20.06.2013.

${ }^{45}$ STJ, REsp 1853369 / CE, $2^{\text {a }}$ Turma, Min. Rel. Herman Benjamin, j. 05.03.2020.

46 “3. Consoante o entendimento do STJ, a correção monetária e os juros de mora, como consectários legais da condenação principal, possuem natureza de ordem pública e podem ser analisados pelas instâncias ordinárias até mesmo de ofício." - STJ, EDcl no AgRg no Ag 1363193 / RS, 1ª Turma, Min. Rel. Gurgel de Faria, j. 08.10.2019.

${ }^{47}$ STJ, AgRg no AREsp 572243/PR, 3 a Turma, Min. Rel. Marco Aurélio Bellizze, j. 24.04.2018.

48 "Por fim, pode-se reconhecer ainda não haver preclusões para alegação de matérias cognoscíveis ex officio, ao menos até o advento da coisa julgada (ainda que em sua dimensão formal)."'- SICA, Heitor Vitor Mendonça.
} 


\section{Também elucida Humberto Theodoro Júnior:}

"A preclusão, sobretudo a temporal, está intrinsecamente relacionada com a disponibilidade do direito ou faculdade processual conferidos à parte pela lei. Há, pois, um consenso em torno de sua não aplicabilidade às questões ou matérias que envolvem a ordem pública. É por isso que o legislador processual, quando se depara com temas dessa natureza, afasta-se do sistema geral da preclusão para conferir ao juiz o poder-dever de conhecer da matéria, sem depender de provocação da parte, isto é, de ofício. É que, em tais situações, mais do que o interesse do litigante, sobressai o interesse público no bom e adequado desempenho da jurisdição. Não se pode esquecer que o processo é o instrumento de atuação de uma das funções soberanas do Estado Democrático de Direito. Não opera a preclusão, portanto, pelo simples motivo de que o litigante não tem disponibilidade de ordem pública." ${ }^{49}$

Trata-se de compreensão inevitável diante do estabelecimento de pedidos implícitos, conforme artigo $322, \S 1^{\mathrm{o}}{ }^{50}$ e artigo $342, \mathrm{II}^{51}$, ambos do CPC.

Teresa Arruda Alvim, ao se debruçar sobre este tema, leciona com maestria: "O pedido expresso é desnecessário quando se trata de (a) juros legais, (b) correção monetária, (c) verbas de sucumbência e (d) honorários de advogado. 2.1. Não há, propriamente, inovação nesta regra, mas consideramos conveniente que a lei se refira a estes bens jurídicos de forma expressa. Até porque isto pode deixar de vez claro que os juros que se podem considerar pedidos implicitamente são só os legais. "52

A mesma autora, quanto à dinâmica do artigo 507 do CPC, bem destaca que inexiste preclusão para questões de ordem pública. ${ }^{53}$

In: BUENO, Cassio Scarpinella (Coord.). Comentários ao código de processo civil, volume 1, arts. $1^{\circ}$ a 317. São Paulo: Saraiva, 2017, p. 807.

${ }^{49}$ THEODORO JÚNIOR, Humberto. Curso de direito processual civil, volume I. $61^{\mathrm{a}}$ ed. Rio de Janeiro: Forense, 2020, p. 1091.

50 "Art. 322. O pedido deve ser certo.

$\S 1^{\circ}$ Compreendem-se no principal os juros legais, a correção monetária e as verbas de sucumbência, inclusive os honorários advocatícios."

51 "Art. 342. Depois da contestação, só é lícito ao réu deduzir novas alegações quando:

II - competir ao juiz conhecer delas de ofício;"

${ }^{52}$ ARRUDA ALVIM, Teresa (et al). Primeiros Comentários ao Código de Processo Civil [livro eletrônico]. Ed. 2020. São Paulo: Thomson Reuters Brasil, 2020, Disponível em: https://proview.thomsonreuters.com/launchapp/title/rt/codigos/104783420/v3/page/RL-1.66.

53 "Há, por fim, aquelas sobre as quais as partes podem discutir, com o objetivo de provocar outra decisão: são as que dizem respeito à matéria de ordem pública - fundamentalmente, mas não excepcionalmente, temas ligados aos pressupostos genéricos de admissibilidade de apreciação do mérito (pressupostos processuais e condições da ação). Quanto a estes temas não há, para as partes, preclusão temporal, nem lógica, nem consumativa; esta última, quer para o juiz, quer para as partes" (ARRUDA ALVIM, Teresa (et al). Primeiros Comentários ao Código de Processo Civil [livro eletrônico]. Ed. 2020. São Paulo: Thomson Reuters Brasil, 2020, disponível em: < https://proview.thomsonreuters.com/launchapp/title/rt/codigos/104783420/v3/page/RL$1.66>$ ). 
Aponta, ademais, Luis Guilherme Aidar Bondioli, que é dever do magistrado examinar as questões de ordem pública, as quais não se submetem à preclusão. ${ }^{54}$

Nessa toada, antes da vigência do CPC atual, já se imaginava tal possibilidade ${ }^{55}$.

Por fim, cabe mencionar que o CPC vigente trata de hipóteses específicas para combater a desuniformidade da jurisprudência pátria.

Quanto à interpretação do artigo 406 do CC, há eminente relevância nesse ponto, de modo que já se julgou, em Corte Especial, sobre a aplicação da Taxa SELIC ${ }^{56}$.

Assim, o artigo 927, III e V ${ }^{57}$, do CPC, prevê, além da observância aos acórdãos em incidente de assunção de competência ou de resolução de demandas repetitivas e em julgamento de recursos extraordinário e especial repetitivos, a vinculação de orientação do plenário ou do órgão especial aos quais os juízes estiverem vinculados.

Fredie Didier Jr. explica tal vinculação:

"Há, aí, a previsão de duas ordens de vinculação. Uma vinculação interna dos membros e órgãos fracionários de um tribunal aos precedentes oriundos do plenário ou órgão especial daquela mesma Corte.

Uma vinculação externa dos demais órgãos de instância inferior (juízos e tribunais) aos precedentes do plenário ou órgão especial do tribunal a que estiverem submetidos. Afinal, o precedente não deve vincular só o tribunal que o produziu, como também os órgãos a ele subordinados.

Diante disso, precedentes do: [...]

b) plenário e órgão especial do STJ, em matéria de direito federal e infraconstitucional, vinculam o próprio STJ, bem como TRFs, TJs e juízes (federais e estaduais) a ele vinculados" ${ }^{\prime 5}$.

\footnotetext{
54 "Naturalmente, o fato de se dispensar qualquer manifestação das partes para o exame de certos assuntos no processo não quer dizer que elas não possam exortar o juiz a exercer seu poder-dever de investigá-los. Ao contrário. Tudo o que o juiz deve conhecer de ofício deve ser objeto de manifestação a qualquer tempo das partes, provocando-o a se pronunciar a respeito" - AIDAR BONDIOLI, Luis Guilherme. In: BUENO, Cassio Scarpinella (Coord.). Comentários ao código de processo civil, volume 2, arts. 318 a 538. São Paulo: Saraiva, 2017, p. 100.

${ }^{55}$ Como elucidava Alexandre de Mendonça Wald: "30. Alguns problemas processuais surgiram com referência à possibilidade de conceder ao credor juros não pedidos na inicial, tendo o Código de Processo Civil (LGL1197315) dirimido tal dúvida no seu art. 293, com o seguinte teor: "Os pedidos são interpretados restritivamente, compreendendo-se, entretanto, no principal os juros legais". (MENDONÇA WALD, Alexandre de. Os Juros no Código Civil e a Emenda Constitucional 40. A Constitucionalidade dos arts. 406 e 591 do Código Civil. In: Revista de Direito Bancário e do Mercado de Capitais. Vol. 21, jul.-set./2003).

${ }^{56}$ Cf. STJ, EREsp 727842 / SP, Corte Especial, Min. Rel. Teori Albino Zavascki, j. 08.09.2008.

57 “Art. 927. Os juízes e os tribunais observarão:

$[\ldots]$

V - a orientação do plenário ou do órgão especial aos quais estiverem vinculados."

${ }^{58}$ DIDIER JR., Fredie. Curso de direito processual civil: teoria da prova, direito probatório, decisão, precedente, coisa julgada, processo estrutural e tutela provisória. Salvador: Ed. Juspodivm, 2021, p. 593.
} 
Teresa Arruda Alvim, nesse campo, bem destaca a importância dos precedentes serem seguidos ${ }^{59}$.

E, Daniel Mitidiero, com didática exemplar, enfatiza que: “As cortes de justiça e os juízes a ela ligados não podem deixar de aplicar um precedente apenas por que não concordam com a solução formulada, isto é, com seu conteúdo". ${ }^{60}$

Logo, apesar de ser aconselhável, especialmente ao réu, alegar sobre a incidência da Taxa Selic na primeira oportunidade de sua manifestação nos autos, já que os juros legais entendidos pelo legislador no campo do direito privado se referem a tal taxa, o sistema processual pátrio possibilita que a incidência do artigo 406 do $\mathrm{CC}$, por ser questão de ordem pública e já estar legitimada por precedentes, possa ser preservada de ofício, inclusive, pelos tribunais. Ademais, adverte-se que, havendo prequestionamento ${ }^{61}$ - ainda que ficto $^{62}$ - sobre a matéria, plenamente aconselhável a interposição de Recurso Especial por ofensa à questão federal que, como visto previamente, foi pacificada no Superior Tribunal de Justiça.

Finalmente, a dinâmica de respeito aos precedentes, adotada pelo CPC, nos termos do respectivo artigo 927, reforça a possibilidade de a matéria - por ser de ordem pública ser apreciada, inclusive de ofício, pelos tribunais.

\footnotetext{
59 "O objetivo destes institutos, ou, se se preferir, destes regimes diferenciados de julgamento de ações de recursos, é justamente o de gerar segurança e previsibilidade. Não teria sentido algum se não tivessem de ser respeitados. Sua razão de ser seria brutalmente desrespeitada e sua finalidade inteiramente comprometida". (ARRUDA ALVIM, Teresa (et al). Primeiros Comentários ao Código de Processo Civil [livro eletrônico]. Ed. 2020. São Paulo: Thomson Reuters Brasil, 2020, Disponível em: https://proview.thomsonreuters.com/launchapp/title/rt/codigos/104783420/v3/page/RL-1.66.

${ }^{60}$ MITIDIERO, Daniel. Processo Civil. São Paulo: RT, 2021, p. 320.

61 "A noção de prequestionamento passou a referir-se, ao longo do tempo, à necessidade de que constasse da decisão impugnada a questão federal ou constitucional, porque o texto constitucional faz referência à questão decidida.

Prevaleceu, assim, o entendimento jurisprudencial de que o prequestionamento (= presença da questão na decisão recorrida) é imprescindível ao cabimento do recurso extraordinário e do recurso especial, como se se tratasse de um requisito autônomo de cabimento do recurso extraordinário e do recurso especial.

Resumindo e concluindo: a expressão prequestionamento hoje em dia significa que a questão federal ou que a questão constitucional deve estar presente no acórdão recorrido. Isso significa que a leitura do acórdão, única e exclusivamente, deve revelar a ofensa à lei ou à Constituição Federal, qualificada, neste último caso, pela circunstância de ter ou apresentar repercussão geral."

In: ARRUDA ALVIM, Teresa; DANTAS, Bruno. Recurso Especial, Recurso Extraordinário e a Nova Função dos Tribunais Superiores [livro eletrônico]. São Paulo: Revista dos Tribunais, 2020, Disponível em: https://proview.thomsonreuters.com/launchapp/title/rt/monografias/112806871/v6/page/RB-4.8.

62 "O enfrentamento da questão constitucional ou da questão federal no acórdão recorrido pode ser efetivo ou ficto. O primeiro ocorre quando há expressa decisão da questão no acórdão, sendo que o segundo decorre do fato de a parte ter oposto embargos declaratórios com o fim de prequestionamento (art. 1.025 do CPC)."

In: MARINONI Luiz Guilherme; MITIDIERO, Daniel. Recurso extraordinário e recurso especial. $3^{a}$ ed. São Paulo: Thomson Reuters Brasil, 2019, p. 127.
} 


\section{CONCLUSÃO}

Diante de todo o exposto, resta indubitável a aplicação da Taxa Selic por força do artigo 406 do Código Civil. Toda a discussão doutrinária e as divergências jurisprudenciais a partir da vigência do diploma vigente foram superadas, de modo que o Superior Tribunal de Justiça já pacificou seu entendimento, destacando-se o julgado supracitado pela Corte Especial $^{63}$ e o tema 176 firmado, em sede de recurso especial repetitivo, na sessão de 02 de junho de 2010 do Superior Tribunal de Justiça.

Aconselha-se, claramente, pelo levantamento da matéria na primeira oportunidade de manifestação. Porém, como visto, em termos processuais, demonstrou-se que a matéria pode ser compreendida como de ordem pública, sendo possível, portanto, que os tribunais venham a apreciar a questão de ofício; até mesmo pela dinâmica de respeito aos precedentes, conforme previsto no artigo 927 do CPC.

\section{REFERÊNCIAS:}

AIDAR BONDIOLI, Luis Guilherme. In: BUENO, Cassio Scarpinella (Coord.). Comentários ao código de processo civil, volume 2, arts. 318 a 538. São Paulo: Saraiva, 2017. ARRUDA ALVIM, Teresa (et al). Primeiros Comentários ao Código de Processo Civil [livro eletrônico]. Ed. 2020. São Paulo: Thomson Reuters Brasil, 2020.

CORDEIRO, António Menezes. Direito Bancário. $6^{\text {a }}$ ed. Coimbra: Edições Almedina S.A., 2018.

CORREIA, Alexandre; SCIASIA, Gaetano. Manual de Direito Romano e textos em correspondência com os artigos do Código Civil Brasileiro. Vol. 1. $4^{\mathrm{a}}$ ed. São Paulo: Editora Saraiva, 1961.

DIDIER JR., Fredie. Curso de direito processual civil: teoria da prova, direito probatório, decisão, precedente, coisa julgada, processo estrutural e tutela provisória. Salvador: Ed. Juspodivm, 2021.

\footnotetext{
${ }^{63}$ STJ, EREsp 727842 / SP, Corte Especial, Min. Rel. Teori Albino Zavascki, j. 08.09.2008.
} 
DORNELAS, Larissa Naves de Deus. SELIC: o mercado brasileiro de dívida pública. Campinas: Alínea, 2021.

FONSECA, Rodrigo Garcia da. Os Juros e o Novo Código Civil. In: Revista de Direito Bancário e do Mercado de Capitais. Vol. 26. Out.-dez., 2004.

MARINONI Luiz Guilherme; MITIDIERO, Daniel. Recurso extraordinário e recurso especial. $3^{\text {a }}$ ed. São Paulo: Thomson Reuters Brasil, 2019.

MARTINS-COSTA, Judith. Comentários ao novo Código civil, volume V, tomo II: do inadimplemento das obrigações. Rio de Janeiro: Forense, 2003.

MENDONÇA WALD, Alexandre de. Os Juros no Código Civil e a Emenda Constitucional 40. A Constitucionalidade dos arts. 406 e 591 do Código Civil. In: Revista de Direito Bancário e do Mercado de Capitais. Vol. 21, jul.-set./2003.

MITIDIERO, Daniel. Processo Civil. São Paulo: RT, 2021.

MONTEIRO, Washington de Barros. Curso de direito civil, v. 4. 14ª ed. São Paulo: Saraiva, 1976.

OLIVEIRA, Marcos Cavalcante de. A Taxa Selic e o art. 406 do CC/02. In: Revista dos Tribunais. Vol. 857. Mar., 2007.

PEREIRA, Caio Mário da Silva. Instituições de direito civil. Vol. II. 22 a ed. Rio de Janeiro: Editora Forense, 2009.

RIZZARDO, Arnaldo. Juros no Código Civil de 2002. In: Revista de Direito Bancário e do Mercado de Capitais. Vol. 22, out.-dez./2003.

RODRIGUES, Silvio. Direito civil. Vol. 2. 24ª ed. São Paulo: Saraiva: 2002.

SICA, Heitor Vitor Mendonça. In: BUENO, Cassio Scarpinella (Coord.). Comentários ao código de processo civil, volume 1, arts. $1^{o}$ a 317. São Paulo: Saraiva, 2017.

THEODORO JÚNIOR, Humberto. Curso de direito processual civil, volume I. $61^{\mathrm{a}}$ ed. Rio de Janeiro: Forense, 2020.

VARELA, Antunes. Direito das obrigações, vol. 2. Rio de Janeiro: Forense, 1978. 